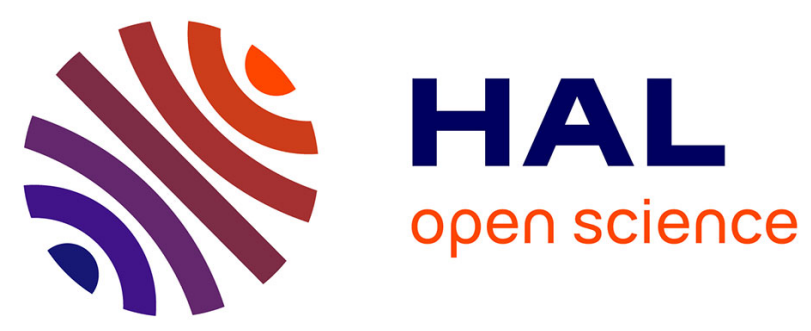

\title{
A rhenium tris-carbonyl derivative as a single core multimodal probe for imaging (SCoMPI) combining infrared and luminescent properties.
}

Sylvain Clède, François Lambert, Christophe Sandt, Zoher Gueroui, Matthieu

Réfrégiers, Marie-Aude Plamont, Paul Dumas, Anne Vessières, Clotilde

Policar

\section{To cite this version:}

Sylvain Clède, François Lambert, Christophe Sandt, Zoher Gueroui, Matthieu Réfrégiers, et al.. A rhenium tris-carbonyl derivative as a single core multimodal probe for imaging (SCoMPI) combining infrared and luminescent properties.. Chemical Communications, 2012, 48 (62), pp.7729-7731. $10.1039 / \mathrm{c} 2 \mathrm{cc} 32163 \mathrm{~g}$. hal-00713189

\section{HAL Id: hal-00713189 \\ https://hal.science/hal-00713189}

Submitted on 27 Nov 2018

HAL is a multi-disciplinary open access archive for the deposit and dissemination of scientific research documents, whether they are published or not. The documents may come from teaching and research institutions in France or abroad, or from public or private research centers.
L'archive ouverte pluridisciplinaire HAL, est destinée au dépôt et à la diffusion de documents scientifiques de niveau recherche, publiés ou non, émanant des établissements d'enseignement et de recherche français ou étrangers, des laboratoires publics ou privés. 


\title{
A rhenium tris-carbonyl derivative as a single core multimodal probe for imaging (SCoMPI) combining infrared and luminescent properties $\dagger$
}

\author{
Sylvain Clède, ${ }^{a b c}$ François Lambert, ${ }^{a b c}$ Christophe Sandt, ${ }^{d}$ Zoher Gueroui, ${ }^{a b e}$ \\ Matthieu Réfrégiers, ${ }^{d}$ Marie-Aude Plamont, ${ }^{f}$ Paul Dumas, ${ }^{d}$ Anne Vessières ${ }^{f}$ and \\ Clotilde Policar* $* a b c$
}

\begin{abstract}
A rhenium tris-carbonyl derivative has been designed to couple infrared and luminescent detection in cells. Both spectroscopies are consistent with one another; they point out the reliability of the present SCoMPI (for Single Core Multimodal Probe for Imaging) for bimodal imaging and unambiguously indicate a localization at the Golgi apparatus in MDA-MB-231 breast cancer cells.
\end{abstract}

The variety of biological issues imposes the use of a wide range of techniques to understand and rationalize intricate biomolecular mechanisms. In this context, bio-imaging techniques are pivotal since they allow direct visualization of labelled biomolecules or organelles. Molecules or tags that can be detected by several complementary techniques offer possibilities of crosscorrelative comparisons. ${ }^{1-3}$ Elaborate molecules showing dual properties, such as fluorescence and magnetic resonance ${ }^{4}$ or fluorescence and radio emission, ${ }^{5}$ have been designed and used as efficient reporters for cell and animal imaging. However, these derivatives are mostly multiple core entities where each covalently bound fragment plays a unique spectroscopic, magnetic or radioactive role, ${ }^{6}$ and whose large size is likely to modify the physico-chemical properties of the tagged molecule.

Fluorescence microscopy is a powerful, widespread technique for cell imaging. Many fluorophores are commercially available for organelle staining and biomolecule tagging. Turnkey filter-cubes adaptable to a large set of molecules allow quick and efficient detection of UV-visible fluorophores, which can also be observed in 3D using confocal fluorescence microscopy.

\footnotetext{
${ }^{a}$ Ecole Normale Supérieure, Département de chimie, 24, rue Lhomond,75005 Paris, France.E-mail: clotilde.policar@ens.fr; Fax: + 33-144323858

${ }^{b}$ Université Pierre et Marie Curie Paris 6, 4, Place Jussieu, 75005 Paris, France

${ }^{c}$ CNRS, UMR7203, 75005 Paris, France

${ }^{d}$ Synchrotron SOLEIL Saint-Aubin, F-91192, Gif-sur-Yvette Cedex, France

${ }^{e}$ CNRS, UMR8640, 75005 Paris, France

${ }^{f}$ Laboratoire Friedel, UMR7223, Chimie ParisTech, 11, rue Pierre et Marie Curie, F-75005 Paris, France

$\dagger$ Electronic supplementary information (ESI) available: Synthesis and chemical characterizations, cell culture, fluorescent organelle staining, nature of the slides, cells incubation for FTIR on a collection of cells, fluorescence imaging, synchrotron radiation FTIR and UV spectromicroscopies, FTIR, UV and fluorescence emission studies. See DOI: $10.1039 / \mathrm{c} 2 \mathrm{cc} 32163 \mathrm{~g}$
}

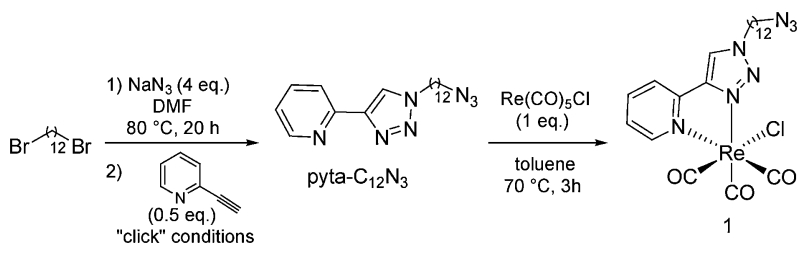

Scheme 1

Infrared spectroscopy involves weaker energies by probing only vibrational levels. Both radiation-induced damages and Rayleigh scattering (proportional to $1 / \lambda^{4}$ ) are weaker than in the UV-visible range. Since infrared wavelength absorption is specific for a given chemical bond, it allows chemical mapping of endogenous ${ }^{7,8}$ (amide, phosphate) and exogenous compounds such as metal-carbonyl derivatives. ${ }^{9-12}$ Interestingly, metalcarbonyl units have also been used in fluorescent cellimaging. ${ }^{2,5,13-16}$ However, to our knowledge, multimodal detection involving both luminescence and infrared vibrational spectro- and microscopies has not been performed yet.

We show here that correlative studies can be efficiently carried out with multimodality arising from a unique molecular core- Single Core Multimodal Probe for Imaging, SCoMPInamely, a single rhenium tris-carbonyl moiety (1, see Scheme 1) that has been designed to display infrared and luminescent properties, easily recognizable from endogenous cell response. This imaging approach indicates that $\mathbf{1}$ localizes to the Golgi apparatus of MDA-MB-231 cells.

Metal tris-carbonyl moieties (including Mn, Re, Os) have been used as IR-labels ${ }^{17}$ in few cases of subcellular mapping (IR or Raman). ${ }^{9-12} C_{3 \mathrm{v}}$ local symmetry of $\mathrm{M}(\mathrm{CO})_{3}$ complexes induces two bands of absorption in the IR-transparency window of the cell: E-band (asymmetric stretching, doubly degenerate) at about $1920 \mathrm{~cm}^{-1}$ and $\mathrm{A}_{1}$-band (symmetric stretching) at about $2020 \mathrm{~cm}^{-1} \cdot{ }^{18}$ These strong carbonyl absorptions previously allowed the mapping inside MDAMB-231 breast cancer cells of an organometallic rhenium tris-carbonyl complex analogous to tamoxifen. ${ }^{11,19}$

To correlate IR chemical mappings with fluorescence microscopy, a mixed organometallic and coordination complex was designed as follows: the IR fragment was kept, as it was shown to be a reliable probe in biological media, ${ }^{11}$ and a 4-(2-pyridyl)1,2,3-triazole ligand (or pyta) was introduced into the coordination 
sphere of rhenium..$^{20,21}$ In similar complexes presenting low $\pi^{*}$ orbitals on ligands, radiative metal-to-ligand charge transfer (MLCT) states are attainable upon excitation in the UV (about $330 \mathrm{~nm}$ ) region and emit at around $520 \mathrm{~nm}^{22}$ A lipophilic long alkyl side chain was introduced to encourage cellular uptake. ${ }^{23}$ Azide terminal function was added in order to compare infrared signals from $\mathrm{N}_{3}$ and $\mathrm{CO}$ groups. Compound $\left[\mathrm{ReCl}(\mathrm{CO})_{3}\right.$-pyta- $\left.\mathrm{C}_{12} \mathrm{~N}_{3}\right] \mathbf{1}$ was synthesized as depicted in Scheme 1, using a "click-to-chelate" strategy. ${ }^{24}$ Its distribution in MDA-MB-231 breast cancer cells (incubation for $1 \mathrm{~h}$ at $37^{\circ} \mathrm{C}$ in the 10-micromolar range; see ESI $\dagger$ ) was studied using a bimodal approach: IR and luminescence imaging was performed, pointing out its localization to the Golgi apparatus.

IR spectra were recorded in the $1850-2200 \mathrm{~cm}^{-1}$ range corresponding to the IR-transparency window of a typical eukaryotic cell. ${ }^{17}$ The FTIR spectrum of compound $\mathbf{1}$ (solid form, Fig. 1A-b) shows both $\mathrm{E}$ and $\mathrm{A}_{1}$-bands characteristic of the $\operatorname{Re}(\mathrm{CO})_{3}$ moiety, at 1920 and $2025 \mathrm{~cm}^{-1}$, respectively, and a weak absorption at $2096 \mathrm{~cm}^{-1}$ corresponding to the azide moiety. UV absorption bands at $300 \mathrm{~nm}$ have been assigned to intraligand $\pi-\pi^{*}$ transitions while the broad $320-350 \mathrm{~nm}$ absorption band is attributed to the MLCT transition (Fig. S1, ESI $\dagger){ }^{20,21}$ Irradiation in this band triggers a large radiative emission band at $c a .510 \mathrm{~nm}$, characterized by a quantum yield of $0.19 \%$ in a water : ethanol $(1: 1)$ mixture at room temperature (Fig. 1B-c and Table S1, ESI $\dagger$ ).

MDA-MB-231 cells were grown on slides (see ESI $\dagger$ ), and incubated with 1 in the 10-micromolar range for $1 \mathrm{~h}$. They were observed in wide field fluorescence microscopy: images and intensity profiles pointed out perinuclear location of $\mathbf{1}$ (Fig. 2 and Fig. S2 (ESI $\dagger$ ), green), with the nucleus stained with DAPI (Fig. 2 and Fig. S2 (ESI $\dagger$ ), blue). Confocal microscopy confirmed that the molecule was localized outside the nucleus: Fig. S3 (ESI $\dagger$ ) shows a typical distribution of 1 (green) close to and underneath the nucleus (blue).

Single cells were mapped using SR-FTIR-SM in mid-IR. Maxima of absorption (or hot spots, see ESI $\dagger$ ) for several
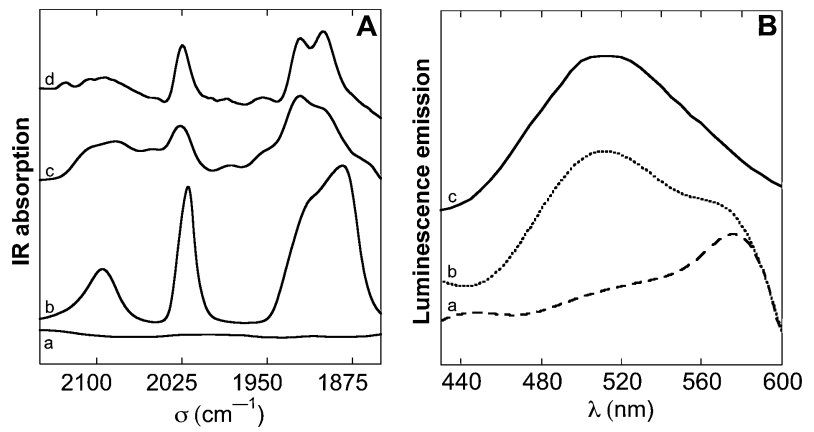

Fig. 1 (A) IR spectra in the cell transparency window: (a) FTIR spectrum of a collection of control cells deposited on a nitrocellulose membrane; (b) FTIR spectrum of solid compound 1; (c) FTIR spectrum of a collection of cells incubated with $1(25 \mu \mathrm{M}, 1 \mathrm{~h}$, about 41000 cells) and deposited on a nitrocellulose membrane; (d) SR-FTIR-SM spectrum (recorded at the black cross in Fig. 3g) on a single cell incubated with $1(10 \mu \mathrm{M}, 1 \mathrm{~h})$. (B) Emission spectra (exc. $350 \mathrm{~nm}$ ): (a) of a MDA-MB-231 single control cell, (b) of a MDA-MB-231 single cell incubated with $1(10 \mu \mathrm{M}, 1 \mathrm{~h})$, (c) of a $6.0 \times 10^{-5} \mathrm{M}$ solution of 1 in water : ethanol 1:1. Spectra (a) and (b) recorded at the DISCO beamline (see ESI $\dagger$ ).
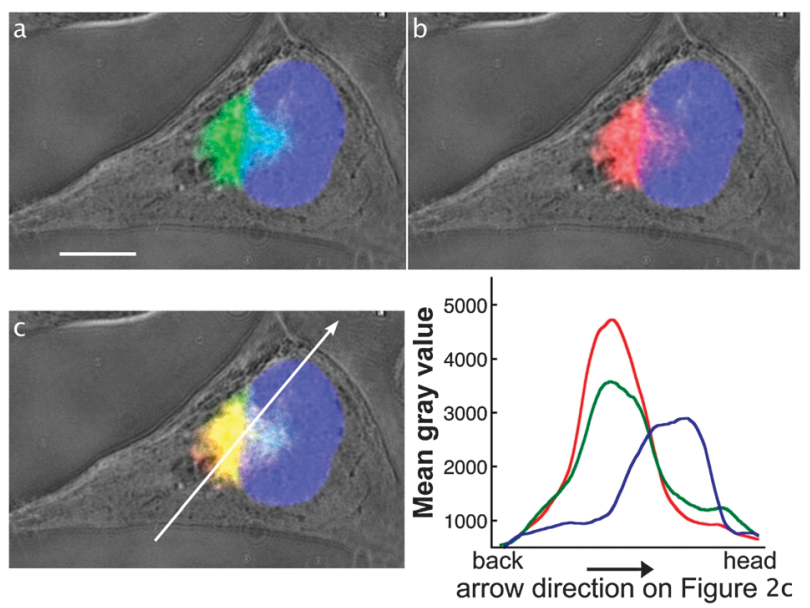

Fig. 2 MDA-MB-231 cell incubated with $1(25 \mu \mathrm{M}, 1 \mathrm{~h})$ and the Golgi tracker. Bright field image (scale bar $10 \mu \mathrm{m}$ ) superimposed to epifluorescence images: (a) merge of $\mathbf{1}$ (green) and DAPI (blue); (b) merge of the Golgi tracker (red) and DAPI (blue); (c) merge of $\mathbf{1}$ (green) and the Golgi tracker (red) with their overlay in yellow and DAPI (blue). Intensity profiles along the arrow on (c) image: 1 (green trace), Golgi tracker (red trace), DAPI (blue trace).

IR-bands are displayed in Fig. 3. Hot spots of $E$ and $A_{1}$-bands of 1 correspond to each other (Fig. $3 \mathrm{c}$ and d: $\mathrm{E}$ in red and $\mathrm{A}_{1}$ in cyan respectively, and Fig. 3g: overlay in white), showing that it is possible to detect $\mathbf{1}$ in a single cell using either the $\mathrm{E}$ or $\mathrm{A}_{1}$-band.

Moreover, the radiative emission signal of $\mathbf{1}$ on the same cell (green area in Fig. 3e) matched the $\mathrm{E}$ and $\mathrm{A}_{1}$-hot spots. These results provide evidence for the integrity of the bimodal core of $\mathbf{1}$ in an intracellular environment and the reliability of the bimodal IR and luminescence imaging.

Phosphate (asymmetric stretching, $1240 \mathrm{~cm}^{-1}$, Fig. 3b, green) and amide (not shown) hot spots are colocalized and partly overlaid (Fig. 3f, yellow) with the E-band (red). As phosphate and amide hot spots are nucleus IR-signature, ${ }^{7}$ these IR-mappings also point out a spatial proximity between 1 and the nucleus. Although the resolution of SR-FTIR is

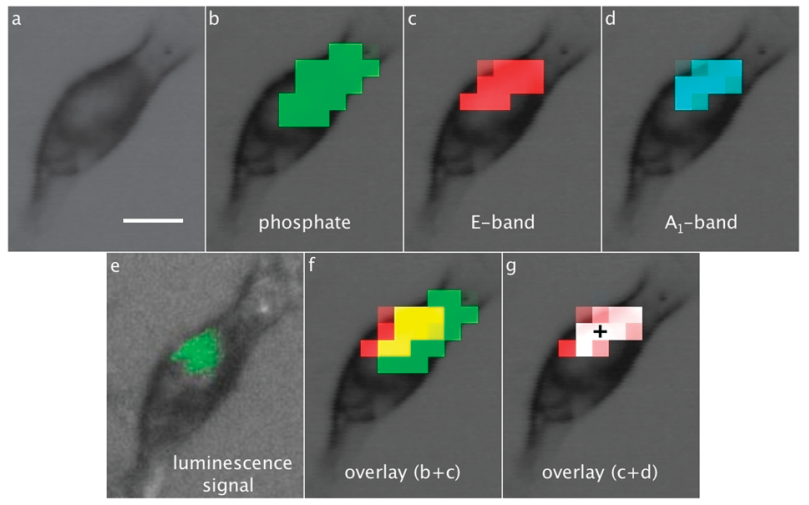

Fig. 3 MDA-MB-231 cell incubated with $1(10 \mu \mathrm{M}, 1$ h). (a) Bright field image (scale bar $10 \mu \mathrm{m}$ ). (b-d) SR-FTIR mappings, hot spots (see ESI $\dagger$ ) (pixel size: $3 \times 3 \mu^{2}$ ): (b) phosphate asymmetric stretching (green), (c) E-band (red), (d) $\mathrm{A}_{1}$-band (cyan). (e) Epifluorescence image, localization of $\mathbf{1}$ (green). (f-g) Overlays of SR-FTIR hot spots: (f) overlay (yellow) of b (green) and c (red), (g) overlay (white) of c (red) and d (cyan). The black cross on (g) locates the d trace in Fig. 1A. 
diffraction limited (Abbe criteria, resolution of $c a . \lambda / 2$ ) with a pixel set to $3 \times 3 \mu^{2}$ these mappings are consistent with the fluorescence studies. Additional IR and luminescence mappings are presented in Fig. S4 (ESI $\dagger$ ).

To confirm the attribution of the IR and fluorescent mappings to $\mathbf{1}$, spectra have been recorded for a collection of cells (FTIR) or at the single-cell level (SR-FTIR and SR-UV-SMs). The IR-signals of $\mathbf{1}$ were observed in a FTIR spectrum of cells ( $c a .41000)$ incubated with 1 and deposited on the nitrocellulose membrane (Fig. 1A-c). The SR-FTIRSM spectrum (Fig. 1A-d) was recorded for a single cell at the black cross shown in Fig. 3g. Both spectra matched that of the solid compound (Fig. 1A-b). Interestingly, the weak asymmetric stretching of the azide group at $2096 \mathrm{~cm}^{-1}$ was also detected in the two cases (single cells and cell collection). None of these signals were found on control cells (Fig. 1A-a). As observed in IR spectroscopy, the fluorescence emission spectrum of cells incubated with 1 (Fig. 1B-b) matched that of the pure compound in solution (Fig. 1B-c) with interestingly weak cellular autofluorescence in the $480-540 \mathrm{~nm}$ range (considering the endogenous emission of control cells in Fig. 1B-a).

To investigate the perinuclear distribution of $\mathbf{1}$, its accumulation in the Golgi apparatus was queried, since Golgi bodies are located close to the nuclear envelope. ${ }^{25}$ The Golgi apparatus is also known to be targeted by lipophilic derivatives, ${ }^{26}$ which is the case for $\mathbf{1}$ with its organometallic core and its long side chain. In addition, a localization in the Golgi apparatus has been previously suspected for a lipophilic rhenium triscarbonyl orthophenanthroline complex coupled with biotin. ${ }^{27}$ In Fig. 2, colocalization experiments using a Golgi tracker, the BODIPY $^{\circledR}$ TR $\mathrm{C}_{5}$-ceramide complexed to BSA, show an overlay (yellow) between $\mathbf{1}$ (green) and this tracker (red) with similar intensity profiles across the cell. Quantitative analyses strongly suggest the colocalization of $\mathbf{1}$ with the Golgi apparatus (Fig. 2: Pearson's coefficient 0.93, overlap coefficient 0.96 , intensity correlation quotient 0.41 , see $\mathrm{ESI} \dagger$ ).

In conclusion, we report here the first successful bimodal subcellular imaging of a single core organometallic multimodal probe using both its infrared and luminescent signatures. The SCoMPI 1, whose single metal-centered core combines both modalities, displays photophysical properties allowing its univocal detection in cells. Both spectromicroscopies are consistent with one another and show a perinuclear location of 1 that was assigned to the Golgi apparatus. Other metal$\mathrm{CO}$ derivatives have been found to be accumulated in specific organelles. ${ }^{10,11,13,28-30}$ These various locations show that these probes can be delivered to different cell-compartments depending on their appended moiety, which is a valuable property for imaging applications. ${ }^{13}$

Since infrared and luminescence spectroscopies are complementary for bio-detection and bio-imaging, IR-luminescent $(\mathrm{L}) \operatorname{Re}(\mathrm{CO})_{3}$ SCoMPIs are of great potential and their multiple modalities open up wide prospects for cross-correlative studies in biological media. IR bio-imaging is emerging, with potential applications at the tissue level. The elaboration of this small molecule chemistry to target organelles or tag molecules for imaging is likely to contribute substantially to our molecular-level understanding of chemical processes in cells.
ENS, CNRS (PIR-CNRS-PCV-prise de risque, UMR8640, 7203), UPMC-Paris 6 are acknowledged for financial support and ENS for SC's PhD fellowship. We thank SOLEIL committee for beamtime (project 20100758).

\section{Notes and references}

1 P. Hildebrandt and R. Weissleder, Curr. Opin. Chem. Biol., 2010, 14, 71-79.

2 A. Louie, Chem. Rev., 2010, 110, 3146-3195.

3 K. Zelenka, L. Borsig and R. Alberto, Bioconjugate Chem., 2011, 22, 958-967.

4 T. Koullourou, L. S. Natrajan, H. Bhavsar, S. J. A. Pope, J. Feng, J. Narvainen, R. Shaw, E. Scales, R. Kauppinen, A. M. Kenwright and S. Faulkner, J. Am. Chem. Soc., 2008, 130, 2178-2179.

5 M. Bartholoma, J. Valliant, P. Maresca Kevin, J. Babich and J. Zubieta, Chem. Commun., 2009, 493-512.

6 H. C. Manning, T. Goebel, R. C. Thompson, R. R. Price, H. Lee and D. J. Bornhop, Bioconjugate Chem., 2004, 15, 1488-1495.

7 E. Gazi, J. Dwyer, N. P. Lockyer, J. Miyan, P. Gardner, C. Hart, M. Brown and N. W. Clarke, Biopolymers, 2005, 77, 18-30.

8 A. Dazzi, R. Prazeres, F. Glotin, J. M. Ortega, M. Al-Sawaftah and M. de Frutos, Ultramicroscopy, 2008, 108, 635-641.

9 K. V. Kong, W. Chew, L. H. K. Lim, W. Y. Fan and W. K. Leong, Bioconjugate Chem., 2007, 18, 1370-1374.

10 K. Meister, J. Niesel, U. Schatzschneider, N. Metzler-Nolte, D. A. Schmidt and M. Havenith, Angew. Chem., Int. Ed., 2010, 49, 3310-3312.

11 C. Policar, J. B. Waern, M. A. Plamont, S. Clède, C. Mayet, R. Prazeres, J.-M. Ortega, A. Vessières and A. Dazzi, Angew. Chem., Int. Ed., 2011, 50, 860-864.

12 P. Hildebrandt, Angew. Chem., Int. Ed., 2010, 49, 4540-4541.

13 V. Fernandez-Moreira, F. L. Thorp-Greenwood and M. P. Coogan, Chem. Commun., 2010, 46, 186-202.

14 A. J. Amoroso, M. P. Coogan, J. E. Dunne, V. FernándezMoreira, J. B. Hess, A. J. Hayes, D. Lloyd, C. Millet, S. J. A. Pope and C. Williams, Chem. Commun., 2007, 3066-3068.

15 K. A. Stephenson, S. R. Banerjee, T. Besanger, O. O. Sogbein, M. K. Levadala, N. McFarlane, J. A. Lemon, D. R. Boreham, K. P. Maresca, J. D. Brennan, J. W. Babich, J. Zubieta and J. F. Valliant, J. Am. Chem. Soc., 2004, 126, 8598-8599.

16 M.-W. Louie, T. T.-H. Fong and K. K.-W. Lo, Inorg. Chem., 2011, 50, 9465-9471.

17 G. Jaouen, A. Vessières and M. Salmain, Bioorganometallics: Biomolecules, Labeling, Medicine, 2006, ch. 1 and 8.

18 M. Salmain, A. Vessières, G. Jaouen and I. S. Butler, Anal. Chem., 1991, 63, 2323-2329.

19 S. Clède, F. Lambert, C. Sandt, Z. Gueroui, N. Delsuc, P. Dumas, A. Vessières and C. Policar, Biotechnol. Adv., 2012, DOI: 10.1016 j.biotechadv.2012.01.023.

20 M. Obata, A. Kitamura, A. Mori, C. Kameyama, J. A. Czaplewska, R. Tanaka, I. Kinoshita, T. Kusumoto, H. Hashimoto, M. Harada, Y. Mikata, T. Funabiki and S. Yano, Dalton Trans., 2008, 3292-3300.

21 A. Boulay, A. Seridi, C. Zedde, S. Ladeira, C. Picard, L. Maron and E. Benoist, Eur. J. Inorg. Chem., 2010, 5058-5062.

22 X.-Y. Wang, A. Del Guerzo and R. H. Schmehl, J. Photochem. Photobiol., C, 2004, 5, 55-77.

23 B. S. Chhikara, D. Mandal and K. Parang, J. Med. Chem., 2012, 55, 1500-1510.

24 H. Struthers, B. Spingler, T. L. Mindt and R. Schibli, Chem.-Eur. J., 2008, 14, 6173-6183.

25 Y. Xiang and Y. Wang, Cell Tissue Res., 2011, 344, 365-379.

26 C. Meisslitzer-Ruppitsch, C. Roehrl, C. Ranftler, J. Neumueller, M. Vetterlein, A. Ellinger and M. Pavelka, Histochem. Cell Biol., 2011, 135, 159-171.

27 K. K.-W. Lo, M.-W. Louie, K.-S. Sze and J. S.-Y. Lau, Inorg. Chem., 2008, 47, 602-611.

28 A. J. Amoroso, R. J. Arthur, M. P. Coogan, J. B. Court, V. Fernandez-Moreira, A. J. Hayes, D. Lloyd, C. Millet and S. J. A. Pope, New J. Chem., 2008, 32, 1097-1102.

29 P. Schaffer, J. A. Gleave, J. A. Lemon, L. C. Reid, L. K. K. Pacey, T. H. Farncombe, D. R. Boreham, J. Zubieta, J. W. Babich, L. C. Doering and J. F. Valliant, Nucl. Med. Biol., 2008, 35, 159-169.

30 W. Hu, K. Splith, I. Neundorf, K. Merz and U. Schatzschneider, JBIC, J. Biol. Inorg. Chem., 2012, 17, 175-185. 